\title{
When Do Political Parties Protest Election Results?
}

\section{Svitlana Chernykh'}

\begin{abstract}
Often, one or more of the parties participating in an election refuse to comply with the announced results and frequently resort to extra-legal strategies to dispute electoral outcomes. Such protests frequently turn violent, occasionally with major repercussions for political stability and the process of democratization. But, why do some political parties use legal avenues to reject electoral outcomes whereas others go outside of the established legal routes? Based on the original data from new democracies in Eastern Europe and the former Soviet Union from 1990 to 2009, I show that political parties are more likely to reject electoral outcomes using extra-legal means when election-related institutions have been changed prior to an election. This study demonstrates the importance of accounting for pre-election day factors when analyzing post-electoral disputes. It also contributes to the literature by presenting a new conceptual framework for studying electoral compliance.
\end{abstract}

\section{Keywords}

post-electoral protests, electoral institutions, international election observation, election fraud

Since the 1990s, there has been a significant increase in the number of elections monitored by international observers. Parallel to the increase in

'University of Oxford, UK

\section{Corresponding Author:}

Svitlana Chernykh, University of Oxford, School of Interdisciplinary Area Studies, 12

Bevington Road, Oxford, OX2 6LH, UK.

Email: svitlana.chernykh@lac.ox.ac.uk 
monitoring, conducting acceptable elections increasingly carries potential international benefits, ${ }^{1}$ such that many incumbents now prefer to retain power through apparently democratic elections. This twin increase has affected the strategic incentives attached to electoral manipulations by incumbents. To conduct a sufficiently democratic election that both domestic and international audiences will believe in, incumbents have been forced to shift away from election-day violations to other less scrutinized stages of the electoral process, such as the pre-electoral stage (Hyde \& O'Mahony, 2010; Simpser \& Donno-Panayides, 2012).

Analysts have begun to explore how this trend creates new challenges for international election monitoring groups (Bjornlund, 2004) and alters incentives of opposition parties to participate in the election (Beaulieu \& Hyde, 2009; Kelley, 2012). However, we know very little about how this development affects the strategies of opposition parties following electoral defeat. Political parties that lose elections have a range of options when they decide how to respond to electoral defeat. They can accept electoral outcomes, let the winner take office, and wait to compete in the next election. Alternatively, they can decide to reject electoral outcomes and question the validity of the results in the courts, on the streets, or both. Why do political parties accept electoral results in some elections but refuse to accept defeat in others? More importantly, why do political parties seek legal redress in some elections yet go outside of the established legal routes in others?

Much of the conventional comparative scholarship has focused primarily on election quality or monitors' assessments when trying to explain why losing parties reject electoral outcomes. However, the fundamental difficulty is that election fraud is too broad of a concept to have any useful explanation for post-election strategies of political parties. Election fraud may take many forms. Schedler (2002a), for instance, provides an entire "menu of manipulation" that incumbent can use. Thus, it is frequently unclear which particular manipulation strategy triggered party's decision to reject electoral results. Electoral fraud is also an illicit activity, which makes it difficult to observe it empirically. As a solution, scholars frequently rely on assessment of election monitors to measure electoral fraud. However, monitors' assessments themselves are a function of many factors and they cannot answer what makes political parties pursue legal avenues for contesting results in some elections yet call their supporters to the streets in others.

I argue that while incumbent governments have learned to strategically adapt their manipulation strategies to the changing world of monitored elections, this has not gone unnoticed by opposition parties. Electoral politics in Georgia and Azerbaijan illustrate that opposition parties pay particular 
attention to pre-electoral developments when making their judgments about the fairness of electoral contests. Georgian opposition parties, for example, already had an opinion about the quality of the November 2003 elections as early as April 2003, when they organized anti-government rallies demanding free and fair elections and the appointment of a new Central Electoral Commission (CEC). Similarly, in Azerbaijan, opposition parties held a number of nationwide protests as early as May 1998 against the government's failure to ensure democratic conditions for the upcoming presidential elections scheduled for October of that year. ${ }^{2}$ This evidence suggests that we need to examine the politics before elections more closely to understand why political parties reject electoral outcomes and, most importantly, how they do it.

My theoretical framework draws on extant theories of the effects of political institutions. Most scholars agree that election-related rules matter for the behavior of political actors. Electoral institutions have been analyzed as important in accounting for a wide range of political phenomena, including the number of parties in a political system (Cox, 1997; Duverger, 1954), the degree of disproportionality (Lijphart, 1994), coalition formation (Golder, 2006), government instability (Mainwaring, 1993; Lijphart, 1984), and women's representation (Norris, 2004; Paxton \& Hughes, 2007), to name a few. Thus, the rules and institutions that govern the electoral process have powerful consequences for political actors - they shape electoral outcomes, thereby influencing a political party's access to the policy-making process. However, there is a paucity of research that explicitly assesses the effects of institutions on the post-electoral compliance of political parties.

Several scholars have examined the dynamics of post-electoral disputes (Bunce \& Wolchik, 2010; Way, 2008) and the impact institutions have on the quality of elections (Birch, 2007a; 2007b). However, although this body of work has made important contributions to the study of elections, it remains incomplete in two ways. First, most of the literature focuses on when the parties are successful in overturning electoral outcomes rather than on the reasons that led them to reject the results and the strategies they used to do so. Second, and more importantly, despite the clear significance of institutions to electoral outcomes and election fraud, few empirical studies explicitly include institutions to account for post-electoral rejection.

The study contributes to a rapidly growing literature on electoral compliance in two main ways. First, it differs from most existing research in its explicit focus on why political parties reject electoral outcomes and, more importantly, why they decide to contest the results outside of the established legal routes. Second, it shifts the focus to the pre-electoral stage and considers what happens in the run up to elections. This focus on the pre-electoral 
stage is shared by Simpser and Donno-Panayides (2012), who argue that election monitoring induces incumbents to increase their use of pre-electoral manipulation and thus can have negative effects beyond the election in question.

My theory of post-electoral compliance also shares key features with Schedler's (2002b) nested game theory. An important advantage of my theoretical model of institutions and compliance is that it yields testable empirical predictions about the relationship between political institutions, post-electoral compliance, and electoral outcomes in developing countries. It also helps to explain not only why political parties reject electoral results but also the strategies they choose to do so. I assess these predictions using an original data set of electoral compliance in 22 countries in Eastern Europe and the former Soviet Union between 1990 and 2009 and find that pre-electoral institutional changes are systematically related to the decision of political parties to use extra-legal means to reject electoral outcomes.

The article is organized as follows. In the next section, I develop a theory of institutional manipulation and post-electoral compliance. Then, I discuss the research design and situate my measures within the literature. Next, I test the theory using a series of empirical tests to assess the impact of institutional changes on electoral compliance. I conclude with a summary and discuss the implications of my findings.

\section{The Politics of Electoral Rejection}

A party complies with the results of an election when it explicitly announces that it accepts the outcome and/or refrains from taking actions that question or seek to overturn the outcome. It is important to distinguish between claims of fraud on the part of the losing parties and the actual rejection of the results. Frequently, losing parties concede defeat while also making allegations that fraud was committed. For purposes of this study, verbal denunciation alone is not strong enough to be considered a rejection of the election outcome.

A political party that decides to reject electoral outcomes must choose between two main forms of rejection. First, a political party can take legal action directed at changing the outcome of the election, such as filing a petition to ask for recount, to cancel, or to nullify electoral outcomes. Second, a political party can take actions outside of the legal framework of dispute resolution such as staging a post-electoral mass protest, refusing to recognize the newly elected legislature by not taking its seats, or boycotting the second round of election. These legal and extra-legal forms of rejection are not mutually exclusive; often parties adopt both courses of action. In Iran in 2009, for instance, Mir Hussein Mousavi called his supporters to the streets to protest 
the electoral outcomes but at the same time lodged an official appeal against the electoral results with the Guardian Council.

In trying to understand electoral rejection, existing studies thus far have focused on a single strategy of rejection-mass post-electoral protest. However, to study electoral compliance systematically, we need to recognize that post-electoral protest is not always available to a political party. Even though a party may choose to stage a post-electoral protest, the protest may not materialize due to logistical, communication, or other problems. Political parties that decide to reject electoral outcomes may not be able to assemble enough protesters to have a significant political impact. They may lack organizational resources, or the government may credibly threaten to crack down on protests and successfully intimidate losing parties and their supporters, or the electorate may simply be apathetic. ${ }^{3}$

Unfortunately, threats of repression or successful intimidation of opposition parties and their supporters leave little observable evidence to account for them empirically (Hyde, 2011; Kuran, 1995). ${ }^{4}$ Thus, treating post-electoral protest as the only indication of electoral rejection is problematic. It is both plausible and reasonable that some parties that are dissatisfied with an electoral outcome may use strategies other than post-electoral protest to voice their rejection. Boycott of the second electoral round or refusal to take seats in the newly elected legislature are also extra-legal means by which political parties can attempt to overturn electoral outcomes. Accounting for the full spectrum of post-electoral tactics available to political parties focuses our attention on the distinction between legal and extra-legal tactics in all their forms and draws us away from debates that are confined to the success or failure of mass protests. After all, political parties have the option of contesting electoral outcomes in the courtrooms and some do, a fact unaccounted for in existing studies of mass protest. Thus, one important question to ask is why political parties opt to employ barricades as opposed to barristers. The remainder of this section outlines when we should expect political parties to reject electoral outcomes using extra-legal means of conflict resolution.

\section{Institutional Changes as Assessment Devices}

Election monitors pay close attention to what happened during the election day (Carothers, 1997; Elklit \& Svensson, 1997; Hartlyn \& McCoy, 2006, Kelley, 2009). As a result, the pre-electoral stage represents the ideal time to make changes that could improve incumbent's chances of victory without attracting the same barrage of criticism incurred by ballot box stuffing. Bjornlund (2004) captures the observer's failure to reconcile effectively 
pre-electoral stage violations and a clean election day in Cambodia's 1998 election:

Despite protestations to the contrary, in the end the standard methodology, even with the presence of long-term monitors and preelection engagement, once again simply focused too much on election day, thus diverting attention from the preexisting flaws. (Bjornlund, 2004, p. 177)

While there are a number of areas that can be affected by pre-electoral manipulation, such as media, administrative effectiveness, and rule of law (Donno \& Simpser-Panayides, 2012; Kelley, 2012), in this article, I focus on three main types of election-related rules that define the main framework within which every election takes place and thereby structure the chances that political parties will have to win: (1) rules governing the electoral system, (2) rules governing the operation of electoral bodies that oversee elections in the country, and (3) rules governing the powers of the executive.

During the pre-electoral stage, electoral rules "constitute one of the major points of contention among opposition elites and incumbents" (Lust-Okar \& Jamal, 2002, p. 340). Electoral rules are chosen by the political actors they govern. Because political actors understand the significance of electoral regulations, they bargain hard for favorable rules and vigorously fight against changes that might hurt their chances of winning elections or accessing the policy-making process. Most importantly, once changed, electoral rules can be indefinitely enforced, carrying their consequences from one election to the next. Thus, political parties have good reasons to worry that the changes to institutions or rules, once in place, will carry not only short- but also longterm consequences for their political health and survival.

\section{Opposition Parties and Pre-Electoral Institutional Changes}

The most important aspect of the explanation of electoral rejection is how the opposition parties perceive institutional changes and how this shapes their subsequent post-electoral strategies. Institutional changes prior to the elections are signals of the incumbent's willingness to alter the institutions if necessary to retain office. Moreover, an abrupt electoral law reform by the incumbent government is also likely to be seen as an indication of electoral vulnerability. In other words, under the current electoral arrangements, the incumbent party would lose or at least not gain its desired majority. Thus, the pre-electoral changes to electoral rules will generate doubts that the incumbent is willing to play fair and may signal to the opposition parties that the incumbent party feels vulnerable. ${ }^{5}$ 
Importantly, however, I argue that this type of manipulation affects not only whether parties reject electoral outcomes but also the strategies they adopt to do it. Let's first consider the possible remedies offered by the legal dispute resolution framework. Electoral disputes can be resolved in three main ways: (1) by providing a formal remedy, which annul, modify, or acknowledge the irregularity; (2) by imposing a penalty on the perpetrator, entity, or person responsible for the irregularity, such as election-related administrative and criminal liabilities; and (3) via some alternative mechanisms for electoral dispute resolution that are voluntary for the parties in dispute and frequently informal (Orozco-Henriquez, 2010, p. 1).

When a political party chooses a legal route to contest electoral outcomes, it files a legal petition, which triggers the first mechanism (modifying/ acknowledging an irregularity) and possibly, the second mechanisms (imposing a penalty). The remedies for electoral grievances available in the case of formal remedies are limited to modification of the electoral results. Although results are occasionally annulled in their entirety and the winner is changed, such instances are very rare. In most cases, a legal complaint triggers a partial recount of the votes with little change to the electoral outcome. The punitive mechanism may result in punishment of a person responsible for electoral violations. However, such punishments, when they happen, rarely affect candidates or political parties directly unless the candidates themselves are jailed.

None of the triggered mechanisms discussed above except for complete annulment of the election include a pathway to remedy the effects of preelectoral manipulation such as an institutional change or credible commitment to conduct the next election under more competitive conditions. The fact that the incumbent was able to change election-related institutions prior to an election reinforces the incumbent's control of the institutional framework making the outcomes discussed above even less likely to happen. This use of power by the incumbent will reduce the opposition's faith in any legal mechanism of contestation. Furthermore, if the motivation for rejection comes from some source beyond electoral defeat, that is, electoral framework, then appealing to the legal mechanism of dispute resolution will not be enough to achieve a desired outcome. Therefore, I argue that if the incumbent has changed the rules governing elections prior to the election, opposition political parties will be more likely to resort to extra-legal means when contesting the outcomes of this election.

What possible benefits can a rejection of electoral outcomes bring for a political party? Perhaps most directly, rejection can force the incumbent to change the election-related rules or improve the conditions under which the next election is conducted. In effect, opposition parties can trade in the 
acceptance of the current electoral outcomes for future changes to the rules or conditions under which elections are held. However, even if the incumbent cannot or will not implement the changes or credibly commit to improving electoral conditions in the future, rejection might still pay off indirectly. Beyond winning institutional concessions, the opposition may use rejection to improve their policy-making position between elections. These changeswhile far short of an institutional change - at least offer the opposition parties some influence over whether the incumbent is able to quickly or easily create more disadvantageous rules or electoral conditions in future elections.

Once the election period is over, opposition parties know that it will be difficult to change the status quo before the next round of elections. The political parties disadvantaged by the new status quo will not only have lost seats, or votes, or access to policy making in the current election cycle, like compounding interest in savings accounts, the deleterious effects of the new status quo can steadily accrue over successive elections, weakening a party and threatening its long-term viability.

Thus, I contend that opposition parties can use elections and immediate post-electoral contest to express dissatisfaction with the existing institutions and laws that govern the elections themselves. In particular, the political parties disadvantaged by the existing electoral laws realize that the provisions cannot be easily changed. Outside of the election period, opposition is unlikely to garner as much attention to the issue of institutional unfairness or clearly demonstrate the effects of it as immediately following the election. Importantly, by rejecting the electoral results, political parties can exert pressure on the incumbent to bargain over the framework of future elections.

If the arguments above are correct, they may help explain why political parties that did not have a chance of winning sometimes decide to reject electoral results. Their objective might be not to simply delegitimize the winner, as is frequently suggested by scholarly and journalistic accounts (Hartlyn, McCoy, \& Mustillo, 2008). Rather, a party's rejection could be aimed at the institutional framework threatening to permanently shut them out of influencing policy making and reduce their electoral prospects in the current and future cycles. ${ }^{6}$ Most importantly, my argument may also help explain why parties in some elections pursue legal mechanisms for contesting electoral outcomes yet take their supporters to the streets in others. Street protests and other extra-legal measures are, I argue, more likely when far-reaching institutional changes are made.

\section{Data}

To test the hypothesis outlined above, I conduct a cross-national statistical analysis of electoral rejection in 22 post-communist countries in Eastern 
Europe and the former Soviet Union between 1990 and December 2009. ${ }^{7}$ There are at least three reasons the focus on the elections in Eastern Europe and the former Soviet Union is warranted.

First, all of the countries in Eastern Europe and the former Soviet Union started holding multiparty elections around the same time, shortly after the collapse of the Berlin Wall in 1989. Within the third wave of democratization, this region allows for the establishment of a non-arbitrary starting point for the analysis, effectively controlling for the duration of the electoral regime by design. Despite the diversity of communist and post-communist regimes in the region, many scholars agree that many internal similarities existed among them prior to 1989 (Bunce \& Wolchik, 2009, 2010; Roberts, 2010).

Second, most of the electoral revolutions that renewed scholarly interest in electoral compliance have taken place in Eastern Europe and countries of the former Soviet Union. Thus, these cases are crucially important to our understanding and explanation of electoral compliance. These events are also some of the most documented electoral rejections on record, allowing for the construction of a more accurate and comprehensive database.

Last, because there has been much more scholarly research on election disputes in Eastern Europe and the former Soviet Union than in other regions, I am able to engage with an existing literature directly.

The sample of elections I have assembled includes national level direct presidential and parliamentary elections in which more than one political party was allowed to participate and for which data were available. This results in a data set containing a total of 182 elections, 73 presidential and 109 parliamentary, in 22 countries.

\section{The Dependent Variable}

As discussed earlier, political parties have a menu of post-election strategies to choose from when they decide how to respond to electoral defeat. The party can (1) comply with electoral outcomes; (2) file a petition to the electoral commission and/or court and ask for recount, cancellation, or annulment of electoral outcomes; (3) stage a post-electoral mass protest ${ }^{8}$; (4) refuse to recognize the newly elected legislature by not taking its seats; and (5) boycott the second round of elections.

I simplify the choice of available strategies to three: comply, legal rejection, and extra-legal rejection. To recall, the election is coded "comply" when all parties either explicitly announce that they accept the outcome and/or refrain from taking actions that question or seek to overturn the outcome. The election is coded "legal rejection" when at least one political party files a legal petition (Strategy 2 above). The election is coded "extra-legal rejection" 
when at least one political party responds in any manner as described in Strategies 3 to 5 above. It is important to recall that legal and extra-legal strategies are not mutually exclusive. Therefore, election is coded as "legal rejection" when a party files a legal petition but does not use Strategies 3 to 5 above.

There are two potential challenges to such coding scheme. First, it is possible that different opposition parties will adopt different strategies following the same election. Some parties may reject whereas other may accept electoral defeat either due to lack of voter support or co-optation on the part of the incumbent (Magaloni, 2010). Ideally, I would also address the question of why some parties reject electoral outcomes and others comply with the same election, but this question will require the analysis at the party level and is beyond the scope of this study. However, more relevant to this analysis is the possibility that parties that rejected the same election chose different strategies to do so (i.e., one party used legal strategy, whereas another party used extra-legal strategy). I examined the data and found only one election in which opposition parties followed different post-election strategies. After electoral defeat in 2008 presidential election in Georgia, three candidates rejected electoral outcomes but only one called his supporters to the streets to protest the outcomes. This election is coded as rejected by extra-legal means.

Second, extra-legal strategies vary in cost and some parties might be able to pursue some strategies but not others. So ideally, we would divide the extra-legal strategy further into categories. I do not pursue this strategy for three reasons. First, there are a relatively small number of rejected elections to begin with. Second, the explanations for different extra-legal strategies will invariably require including analysis at the party level. For reasons of data availability and space, I leave a more complete study of various political party attributes that affect parties' propensity to follow particular extra-legal strategy for future research. Lastly, extra-legal strategies are not mutually exclusive. A party may stage a post-election protest and reject seats it won in the election. But most importantly, my main theoretical argument focuses on the decision to resort to extra-legal means of electoral rejection versus the legal, but it does not provide explanation for why a particular party will choose a particular extra-legal strategy.

Because no previous study has empirically examined different strategies that parties use to contest electoral outcomes, I constructed a cross-national database myself using newspaper sources, Keesing's Archive of World Events, election monitoring reports, and secondary academic literature. I find evidence that political parties used a variety of ways to question the outcomes among which extra-legal means predominated. Political parties questioned the results of $24 \%$ of the elections held in Eastern Europe and the former 
Soviet Union. Eighty percent of the rejected elections were followed by one or more actions taken outside of the legal framework of dispute resolution. Although the detailed breakdown of the post-electoral behavior of political parties around the world is not available, the NELDA data set allows some comparison between my sample and the general population. NELDA reveals that in the general population, $16 \%$ of the elections were followed by mass post-electoral protests, slightly lower than the levels of protests in the postcommunist countries I sample. ${ }^{9}$

\section{Measuring Institutional Changes}

As previously discussed, I focus on three main aspects of election-related rules: (1) rules governing the electoral system, (2) rules governing the operation of electoral management bodies, and (3) rules governing the powers of the executive. I code each case for the presence (1) or absence (0) of a restrictive change in a particular aspect of the rule that was enacted prior to the election.

\section{Electoral Formula}

In the case of electoral rules, I code the change as more restrictive if a law has been enacted that increased the number of seats elected under majoritarian rules, restricted opposition access to public finances, disqualifies opposition candidates, or disenfranchises certain groups of voters on arbitrary grounds (Roberts, Seawright, \& Cyr, 2012; Simpser \& Donno-Panayides, 2012). Coding laws disqualifying opposition parties from participating in the election on arbitrary grounds as restrictive is not controversial. However, it is hard to judge objectively the changes in the electoral formula as more or less restrictive as no particular electoral formula is considered to be universally superior or more democratic than others. My decision to focus on the changes in the share of seats elected in single member districts is primarily motivated by the existing research on electoral systems and electoral manipulation discussed below.

The main distinction I make in the electoral formula is between elections held in single-member districts (SMDs) and elections run in multiple-member districts under the rules of proportional representation (PR). Because the opposition parties in many transitional countries are frequently weak and/or fractionalized, they tend to favor laws that promote representation for smaller parties such as multi-member districts and proportional representation.

SMD, on the other hand, has long been associated with magnifying the success of large parties and is not conducive to an alternation in power. In 
fact, the second largest party frequently gains less than $20 \%$ of the seats under SMD, leaving the opposing weak, at times powerless, against the electoral winner. The system is particularly harmful for countries new to multi-party elections, where the party system is frequently geographically heterogeneous and poorly entrenched. In such situation, SMD will encourage a large number of small, poorly organized, and inexperienced parties and even independents to run in the legislative elections. Consequently, only one party, frequently the authoritarian successor, will be able to fully benefit from the "large party effect" of the system (Birch, 2005; Lust-Okar \& Jamal, 2002).

In her recent work, Birch (2007b) also found a connection between the electoral formula and electoral manipulation. Elections held in SMDs are more likely to be the object of electoral manipulation than elections run under proportional representation rules for two main reasons: (1) There is more to gain from individual efforts to manipulate elections than in the case for candidates in PR and (2) if employed, electoral manipulation is more efficient under SMD rules because the number of votes that need to be altered to change the outcomes is lower than it is under PR.

Importantly, in all the cases under consideration, I find that the opposition parties indeed always resist changes to the electoral system that increase the number of seats elected in SMDs, perceiving it as advantaging the incumbent party. For instance, liberals and the national-democratic opposition vigorously opposed the majoritarian, first-past-the-post electoral system adopted by the Ukrainian parliament on November 18, 1993. They argued that the law would favor the communist deputies and declined to vote on the law, walking out of the parliament in defiance (Commission on Security and Cooperation in Europe [CSCE], 1994). Similarly, opposition parties in Armenia in 2002 widely criticized a new electoral law that increased the number of parliamentary seats based on single-mandate constituencies from 37 to 56 and decreased from 94 to 75 the number of seats elected on a proportional party-list basis. ${ }^{10}$

\section{Electoral Management Bodies}

In the case of electoral management bodies, a restrictive change is coded as "1" if it led to establishment of control or an increase in control by the incumbent party over the appointment of the members of the Central Electoral Commission (CEC). For example, in May 1998, Milli Majlis, Azerbaijan's legislative body, approved a law on the CEC, which designated that 12 members were to be appointed by the president and 12 members by the parliament, which was controlled by the president's party. The opposition vigorously opposed the law and fought for having an equal representation on the CEC, where the president would appoint 12 members and the opposition 
would appoint the remaining $12 .{ }^{11}$ Their concern understandably was that the law would grant total control over the CEC to the president. Changes such as these directly threaten the electoral future of opposition parties.

The importance of the independent electoral bodies that oversee the electoral process has been recognized by the scholars over the past decade starting with a seminal article by Pastor in 1999 (Pastor, 1999). More importantly, opposition parties also recognize the importance of independent electoral commission in ensuring the fairness of the electoral contest. For example, in their reaction to the new election law that changed the composition of the electoral commission prior to the 1996 election in Albania, opposition party leaders claimed that the structure of electoral commissions amounted to a "coup d'etat," after which the Democratic Party would be able to freely manipulate the process (International Republican Institute [IRI], 1996).

In fact, many electoral disputes between the incumbent and the opposition parties center on the composition of electoral commissions. Opposition parties in Georgia expressed their concern with the composition of the electoral commission and fairness of the upcoming election prior to the events of the Rose revolution. In Ukraine, the composition of the electoral commission was changed after the annulment of the December 2004 contest but before the rerun of the second round as a part of the measures to ensure that the rerun of the elections would be held under free and fair conditions.

\section{Executive Dominance}

Last, I code constitutional changes that increase the powers of the executive. Such changes include abolition of term limits, granting the president the right to dissolve the legislature, and subjecting decisions of the judiciary to presidential veto. For instance, on November 1996, Belarus held a referendum initiated by the President Alexander Lukashenko on the increase of presidential powers and term limits; it allowed the president to issue legally binding decrees at will, provided significant powers of appointment to the judiciary and the new legislature, and extended term end date from 1999 to 2001. ${ }^{12}$ This effectively removed opposition parties and the judiciary from the policy-making process. The majority of these changes required a constitutional amendment making them easy to identify and code. ${ }^{13}$

Presidential term limits, in particular, have been recently under attack by the incumbents. However, how do term limits affect the electoral chances of the opposition parties? Analysts document that non-incumbent elections pose serious challenges to the ruling parties by creating succession battles as well as resulting in more transparent and fair elections and thus are more likely to lead to transfer in power (Cheeseman, 2010; Maltz, 2007). Analyzing 
elections in electoral authoritarian regimes between 1992 and 2007, Maltz confirms this trend. Incumbents retained power in $93 \%$ of the elections that they contested while their successors won only $52 \%$ of the time (Maltz, 2007).

Once all the changes have been coded and categorized, I create a dichotomous variable - institutional change - that is coded " 1 " if any restrictive law has been enacted in any of the three areas discussed above. A change that occurred any time after the previous election and before the current elections is coded as affecting the current election. If a country held presidential and parliamentary election in the same year, and the change was enacted prior to these elections, both elections are coded as having been preceded by the change. A total of $18 \%$ of the elections under consideration were preceded by a change in institutional rules. Restrictive electoral changes were enacted in a total of 14 countries.

Ideally, we would have three separate independent variables for each of the rules. However, I find that different types of changes are frequently enacted together making it difficult to assess the impact of each of the type separately. For instance, I find that political parties rejected every election preceded by a change in rules governing the electoral commission. This is a very important finding, which makes changes in the rules governing electoral commissions a sufficient condition for electoral rejection. This is not surprising because such changes are highly salient, directly affecting political party's chances of winning. In addition, the fact that the electoral commission experienced a change that placed it further within the control of the incumbent party would have the effect of making the alternative to extra-legal challenges (i.e., legal challenge) futile. However, 10 out of 11 case changes to the central electoral commission regulations were accompanied by changes in other areas of electoral regulations. Therefore, it is hard to determine whether it is changes to the rules governing the CEC alone or the combination of changes that have such a strong influence on the decision of political parties to reject the electoral outcomes.

\section{Other Explanatory Variables}

To test the hypothesis about the impact the observers' assessments have on parties' post-electoral strategies, I use the Quality of Elections Data (QED; Kelley, 2012). ${ }^{14}$ It codes preliminary statements issued by the observers immediately after the polls close. It is coded as " 0 " if the monitors endorsed the outcome. It is coded " 0.5 " if the monitor's statement about the election was ambiguous, or if the mission openly stated that it has no opinion, or simply was silent. When election monitors explicitly stated that an election did 
not represent the will of the voters, was not free and fair, or otherwise condemned the election, the election is coded as " $1 . " 15$

Observer missions usually issue two types of reports. First, they issue statements immediately after the election, called post-election or preliminary statements in which they provide a summary of their assessment of the election. These initial statements are usually followed by longer, more detailed reports issued months later. The focus on the first type of reports is warranted due of the timing of the reports. When political parties reject electoral outcomes, they frequently do so immediately after the election. Thus, if the decisions of political parties are influenced by the reports of the observers, they will be shaped by the summary assessments issued shortly after the polls close rather than the longer, full reports, which are published long after the post-electoral battles have started.

I find that monitors endorsed around $51 \%$ of the elections that took place in the region since 1990 . Out of the remaining $49 \%$, they openly rejected $22 \%$ of the elections that took place in the region. In $27 \%$ of the cases, monitors either issued an ambiguous verdict or disagreed among themselves regarding the assessment of the elections. This is important because existing theories of electoral quality do not consider what happens when monitors issue an ambiguous verdict refusing to openly endorse or criticize an election.

The percent of endorsed elections in the region is lower than in the world, where $66 \%$ of the elections were declared by the international monitors to be free and fair. The distribution of ambiguous and negative assessments also differs. In Eastern Europe and the former Soviet Union, 27\% of the observers' assessments were ambiguous, compared with only $7 \%$ worldwide. This discrepancy suggests that election monitors in this region are more hesitant to issue a definite verdict. Within the data, this spike in ambiguous verdicts results in fewer negative verdicts $(22 \%)$ than observed worldwide $(27 \%) .{ }^{16}$

In addition to the variables discussed above, I include a number of substantively important variables to account for other factors that may encourage or dissuade political parties from rejecting electoral outcomes as well as affect their mode of rejection. First, I count the number of consecutive victories by the incumbent. In established multi-party competition, political parties have some reasonable expectations of winning an election or, at least, of becoming a part of the government at some point. Often, these expectations are based on experience because "in established democracies, most of today's losers were already yesterday's winners and vice versa" (Moehler \& Lindberg, 2009, p. 1451).

These expectations are different in new democracies, where political parties often have been prevented from competing or even forming under previous regimes. When parties enter the multi-party politics in new democracies, 
the temporary nature of these disadvantages is not always evident, at least, not until the alternation in power is established on the regular basis. Until this happens, the more elections are won by the incumbent the less likely the opposition is to believe that it has a chance of winning. Therefore, political parties may reject electoral outcomes not in response to what the incumbent did prior to the election in questions but rather due to a longer history of incumbent party dominance.

An established literature posits that in rich countries, all political actors will accept electoral results because even electoral losers have too much to lose by rejecting the outcomes (Przeworski, 1991, 2003). Thus, to control for the effect of economic development on political parties' post-electoral behavior, I include a log of GDP per capita. As elections take place during different months in different countries, I use the GDP per capita from the year previous to the given election. ${ }^{17}$ Data on countries' real GDP per capita are from the World Bank. ${ }^{18}$

I also control for the quality of judiciary using a measure of de facto judicial independence (Linzer \& Staton, 2012). ${ }^{19}$ Judicial independence reflects "the ability and willingness of courts to decide cases in light of the law without undue regard to the views of other government actors" (Melton \& Ginsburg, 2012, p. 6). Quality of judicial institutions in the country may affect the willingness of political parties to pursue legal challenges. ${ }^{20}$ It is also reasonable to suggest that extra-legal rejection will be more likely in countries with a history of such rejections. Therefore, I include an indicator variable coded as " 1 " if previous election in the country was rejected by opposition parties using extra-legal strategies.

I also include a measure of human rights abuses to account for the possibility that rejection on the part of political parties is a form of social movement where parties use post-electoral period to contest broader social problems and express anti-regime behavior as opposed to responding to any election-related factors. Eisenstadt (2004), for instance, finds that the Party of the Democratic Revolution (PRD) in Mexico used elections as an opportunity "to contest broader social ills" and initiated post-electoral conflicts in response to the history of social conflict rather than election-related factors (Eisenstadt, 2004, p. 158). On the other hand, it is also important to account for the possibility that human rights violations may serve as a proxy for repression by the government and may deter political parties from rejecting electoral outcomes. Rights violations or repression may also affect the ability of the political parties to stage mass post-electoral protests. In an environment of heavy-handed government repression, citizens will be less likely to rush to the streets in support of political parties that lost. 
Table I. Predicting Electoral Rejection Multinomial Logit Estimates.

\begin{tabular}{|c|c|c|c|c|}
\hline \multirow[b]{2}{*}{ Variable } & \multicolumn{2}{|c|}{ Comply vs. Legal } & \multicolumn{2}{|c|}{ Extra-legal vs. Legal } \\
\hline & (I) & (2) & (I) & (2) \\
\hline Institutional change & - & $0.36(0.53)$ & - & $2.25 * * *(0.59)$ \\
\hline Consecutive victories & - & $-0.99 * * *(0.35)$ & - & $-0.34(0.34)$ \\
\hline De facto judicial independence & - & $7.24 * *(3.55)$ & - & $2.96(3.11)$ \\
\hline Economic development & - & $-0.26(0.61)$ & - & $-1.03 * *(0.49)$ \\
\hline Human rights & - & $-0.49 *(0.29)$ & - & $-0.29(0.24)$ \\
\hline Extra-legal $_{t-1}$ & - & $1.09(0.71)$ & - & $2.11 * *(0.95)$ \\
\hline Democracy & - & $-0.22 * *(0.09)$ & - & $-0.09(0.09)$ \\
\hline Observer assessment & $-3.23 * * *(1.2)$ & - & $0.64(1.21)$ & - \\
\hline Constant & $3.64^{* * * *}(0.84)$ & $6.88(4.83)$ & $0.78(0.93)$ & $10.59 * *(4.23)$ \\
\hline$N$ & 146 & 146 & 146 & 146 \\
\hline Wald $\chi^{2}$ & 15.24 & 463.3 & 15.24 & 463.3 \\
\hline Prob $<\chi^{2}$ & .00 & .00 & .00 & .00 \\
\hline Pseudo $R^{2}$ & .24 & .41 & .24 & .41 \\
\hline Log likelihood & -85.94 & -66.86 & 85.94 & -66.86 \\
\hline
\end{tabular}

Note. Robust standard errors, clustered on country, are in parentheses.

$*_{p} \leq .1 . * * p \leq .05$. *** $p \leq .01$.

Thus, it is hard to predict ex-ante the effect that government repression will have on the rate of rejection. These two reasonable arguments result in contradictory hypotheses. What is clear, although, is that a record of political repression could reasonably affect the political calculations of opposition parties and should be included as a statistical control. To account for political repression, I use Physical Integrity Rights Index, where lower values stand for no respect for rights (Cingranelli \& Richards, 2010).

A final factor to consider is a level of democracy. Scholars argue that democracies are fundamentally different from dictatorships, which in this case directly affects party's post-electoral strategies. Therefore, I include a democracy variable measured using Polity IV scores. The variable is lagged 1 year (Marshall \& Jaggers, 2006).

\section{Explaining Electoral Rejection}

Because rejection is an unordered three-level variable, I use a multinomial logistic regression. I first fit a simple "observer" or "election quality" model. ${ }^{21}$

The results of the first model in Table 1 suggest that observer assessment of the election has an impact on the decision of political parties to reject electoral outcomes via legal routes as opposed to complying. However, monitor assessments do not provide cues for why parties decide to use extra-legal as 
opposed to legal strategies. These results are not surprising. While it is true that parties are more likely to reject elections that receive negative assessments of the international observers, this still is an incomplete explanation for why some parties choose to contest electoral outcomes in the courts and others on the streets.

There is also a possibility of endogeneity. Kelley (2009), for instance, has shown that electoral observer missions may act strategically and sometimes endorse questionable elections to avoid potential crises. ${ }^{22}$ During the 1996 electoral crisis in Albania, the Socialist Party accused electoral observers of endorsing openly fraudulent elections; Western observers justified their decision to avoid criticizing the elections by saying that their goal was to avoid violent instability: "The Albanian people would not be served if we bring them turmoil, as we surely would if we criticize this election" (Gumbel, 1996). At the same time, however, election monitors must be concerned with their own credibility. Therefore, once they realize that their positive assessment will be unable to prevent the growing probability of violence or postelectoral protest, they may criticize the election to preserve their credibility. This suggests that the causality between the monitors' verdict and party's rejection of electoral outcomes may be reversed (Kelley, 2009).

Second model estimates the probability of observing different types of rejection - compliance, legal rejection, or extra-legal rejection-if electionrelated institutions have been changed prior to an election. The model also includes a number of covariates to account for other plausible important factors that might affect parties' choices discussed above. ${ }^{23}$ The results from the model suggest that institutional change provides an important cue for political parties. Consistent with the theory proposed in this article, change in election-related rules increases the likelihood that political parties will use extra-legal means of rejection as opposed to pursuing only legal route of conflict resolution. Institutional change, however, has no impact on a political party's decision to comply with electoral outcomes as opposed to seeking legal redress. Other factors, such as de facto judicial independence, number of consecutive victories, and level of democracy are more important in predicting this.

De facto judicial independence increases the odds that political parties will comply with electoral outcomes as opposed to contesting them in the courts. However, it has no impact on parties' decision to contest electoral results via extra-legal as opposed to legal means. This result is a bit counterintuitive, as we would expect judicial independence to have a positive impact on the decision of political parties to seek legal redress. That said, judicial independence may affect the conduct of the elections themselves, which would explain the decision to comply as opposed to seek legal redress. 
The number of consecutive victories, on the other hand, increases the odds of legal rejection as opposed to compliance. The longer the incumbent party stays in office, the more likely opposition parties are to reject electoral outcomes. The level of democracy also proves to be significant. ${ }^{24}$ However, it affects only choice between compliance and legal rejection but proves to be insignificant in explaining the choice between legal and extra-legal strategies. One possible explanation for this insignificant result is that the measure of democracy is affected by many factors, which may include pre-electoral institutional changes.

Model 2 also controls for economic development, previous rejection, and human rights violations. I find that increase in economic development reduces the odd of extra-legal rejection. This means that political parties in poorer countries are more likely to contest elections using extra-legal than legal means, which provides further support for Przeworski's (1991) hypothesis discussed above. Previous extra-legal rejection, on the other hand, increases the odds that political parties will use extra-legal strategies in the following election. This suggests that an extra-legal rejection may establish a dangerous precedent for resolving electoral disputes through extra-legal channels. Lastly, the results also suggest that human rights violations may increase the odd of legal rejection as opposed to compliance but they do not have an impact on the decision to use extra-legal strategies.

\section{Conclusion}

This article extends the empirical scholarship on electoral compliance. Experts on elections have recently noted that to escape the barrage of criticism of election monitors, incumbent governments intent on cheating often shift their efforts away from election-day violations to other less scrutinized stages of the electoral process. This study sought to evaluate the impact particular factors at the pre-electoral stage have on the post-electoral behavior of opposition parties. I have argued that taking into account pre-electoral institutional changes may help explain not only why political parties decide to reject electoral outcomes but also the strategies they adopt to do it.

The article also proposed a new conceptualization of electoral rejection that offers several distinct advantages over existing work. First, it includes a better representation of the full range of tactics available to political parties following an electoral defeat. The launching of a protest, although clearly an important and consequential method of rejection, is only one of many strategies available to political parties. It is crucial that we take into account the other actions available to political parties such as refusing to take seats in the newly elected bodies or boycotting second rounds of elections. Second, 
accounting for the full spectrum of post-electoral tactics available to political parties focuses our attention on the distinction between legal and extra-legal tactics in all their forms. After all, political parties have an option of contesting electoral outcomes in the courtrooms and some do, a fact unaccounted for in studies of post-electoral protests. One important question that the conceptual framework I propose allows us to ask is why political parties opt to employ barricades as opposed to barristers.

I find that the institutional changes initiated by the incumbent prior to the election are central in accounting for the decisions opposition parties make after the election. To understand the phenomenon of post-electoral rejection, we must expand our analysis beyond the election day to account for the whole electoral process from the pre-electoral actions of the incumbent to the institutional framework that governs the election itself. Only by taking this wider view can we truly hope to capture the causal sequence that leads political parties to reject an election. However, the results in this article make an argument for not only paying a close attention to the pre-electoral events and institutional framework of the election but also, perhaps more importantly, for paying careful attention to motivations and decision-making process of political parties.

The results of this article also suggest that international and domestic actors seeking to advance democratization should prioritize institutional conditions for free and fair elections such as independent electoral commissions and enforced term limits. Perhaps one way to keep incumbents' hands off the institutional scales might be to include some of the election-related provisions in the constitutions. However, commitment and stability may come at the expense of flexibility making it difficult to change the rules in light of experience. Perhaps studies examining the impact of constitutionalization of election-related institutions on electoral compliance will enhance our understanding further.

\section{Acknowledgments}

The author would like to thank the anonymous reviewers, José Antonio Cheibub, Paul Chaisty, Nic Cheeseman, Timothy Power, James Melton, and Milan Svolik, for helpful and insightful comments on earlier versions of this article.

\section{Declaration of Conflicting Interests}

The author(s) declared no potential conflicts of interest with respect to the research, authorship, and/or publication of this article.

\section{Funding}

The author(s) received no financial support for the research, authorship, and/or publication of this article. 


\section{Notes}

1. Such as foreign aid, accession to international organization; for more see Hyde 2011.

2. Keesing's Record of World Events. Azerbaijan. Vol. 44, May 1998.

3. A number of studies argue that the communist regime produced citizens characterized by apathy toward politics (Bernhard \& Karakoç, 2007; Jowitt, 1992)

4. Although, recent work suggested that increased repression may actually spur mass public to go to the streets (Bell \& Murdie, 2011)

5. For an alternative explanation for why incumbents may manipulate elections, see Simpser (2008).

6. By influence over policy I mean both the ability to affect political decisions and/ or create hurdles for further changes in the institutional setting.

7. I start the data collection with the first multi-party election in a country and stop for all countries on December 31, 2009. The only exception is Croatia, for which I include the presidential election that was held on January 10, 2010.

8. Here, I code only cases where political parties explicitly called their supporters to the streets and led the mass demonstration. Existing literature shows that elites have considerable influence on protest in both democratic and non-democratic settings (Reuter \& Robertson, 2013; Robertson, 2007).

9. Author's calculations using NELDA data set (Hyde \& Marinov, 2012).

10. Keesing's Record of World Events. Armenia. Vol. 48, August 2002.

11. Keesing's Record of World Events. Azerbaijan. Vol. 44, May 1998. Another source suggests that opposition demanded 17 out of 24 to be representatives of political parties.

12. Keesing's Record of World Events. Belarus. Referendum on Constitutional Change 42, November 1996.

13. I use data from the Comparative Constitutions Project (Elkins, Ginsburg, \& Melton, 2011) and Donno (2008).

14. Quality of Elections Data's (QED) coverage ends in 2004. Where possible, I extend the original coding to post-2004 elections using the same coding rules.

15. If the election was monitored by more than one organization, I use the "max" variable that denotes the highest value given by an organization. For more details on the variable, see Kelley (2012).

16. Author's calculation using QED (Kelley, 2012).

17. Except for Poland 1990, where 1989 figures is not available, I use 1990 figures to code 1990 elections.

18. Constant 2005 International \$ (World Development Indicators [2011]).

19. See Linzer and Staton (2012) for construction of the variable.

20. I would like to thank an anonymous reviewer for this suggestion.

21. The number of observations reduces to 146, primarily due to the fact that QED's coverage ends in 2004.

22. However, see Hyde (2011).

23. In Model 2, I use the same sample as in Model 1. As mentioned above, the number of observations is reduced due to the missing data on observer assessment 
variable because the coverage of the QED data set ends in 2004. To check the robustness of my results, I also ran Model 2 using all available observations $(N=$ 174). The substantive findings do not change. The Model is not included due to lack of space but is available on request.

24. The results are similar when I use a dichotomous measure of democracy (Cheibub, Gandhi, \& Vreeland, 2010). The model is not shown in the interest of space.

\section{References}

Beaulieu, E., \& Hyde, S. (2009). In the shadow of democracy promotion: Strategic manipulation, international observers, and election boycotts. Comparative Political Studies, 42, 392-415.

Bell, S., \& Murdie, A. (2011). Predictive societal indicators of radicalism. Retrieved from http://radicalism.milcord.com/blog/?page_id=2

Bernhard, M., \& Karakoç, E. (2007). Civil society and the legacies of dictatorship. World Politics, 59, 539-567.

Birch, S. (2005). Single-member district electoral systems and democratic transition. Electoral Studies, 24, 281-301.

Birch, S. (2007a, August). Electoral management bodies and the electoral integrity: Evidence from Easter Europe and the former Soviet Union. Paper presented the Annual Meeting of American Political Science Association, Chicago, IL.

Birch, S. (2007b). Electoral systems and electoral misconduct. Comparative Political Studies, 40, 1533-1556.

Bjornlund, E. (2004). Beyond free and fair: Monitoring elections and building democracy. Baltimore, MD: Johns Hopkins University Press.

Bunce, V., \& Wolchik, S. (2009). Postcommunist ambiguities. Journal of Democracy, 20(3), 93-107.

Bunce, V., \& Wolchik, S. (2010). Defeating dictators: Electoral change and stability in competitive authoritarian regimes. World Politics, 62, 43-86.

Carothers, T. (1997). The observers observed. Journal of Democracy, 8(3), 17-31.

Cheeseman, N. (2010). African elections as vehicle for change. Journal of Democracy, 21(4), 139-153.

Cheibub, J. A., Gandhi, J., \& Vreeland, J. (2010). Democracy and dictatorship revisited. Public Choice, 143, 67-101.

Cingranelli, D. L., \& Richards, D. (2010). The Cingranelli-Richards (CIRI) Human rights data set. Available form http://www.humanrightsdata.org

Commission on Security and Cooperation in Europe. (1994). Ukraine's parliamentary election. Washington, DC: Author.

Cox, G. (1997). Making votes count: Strategic coordination in the world's electoral systems. Cambridge, UK: Cambridge University Press.

Donno, D. (2008). Defending democratic norms: Regional intergovernmental organizations, domestic opposition and democratization (Unpublished Dissertation). Yale University, New Haven, CT.

Duverger, M. (1954). Political parties. London, England: Methuen. 
Eisenstadt, T. (2004). Courting democracy in Mexico: Party strategies and electoral institutions. Cambridge, UK: Cambridge University Press.

Elkins, A., Ginsburg, T., \& Melton, J. (2011). Comparative constitutions project. Available from http://www.comparativeconstitutionsproject.org

Elklit, J., \& Svensson, P. (1997). What makes elections free and fair. Journal of Democracy, 8(3), 32-46.

Europa World Online. (n.d.). Available from http://www.europaworld.com/ welcome? authstatuscode $=200$

Golder, S. (2006). The logic of pre-electoral coalition formation. Columbus: The Ohio State University.

Gumbel, A. (1996, May 31). Europe turns a blind eye to Albanian poll. The Independent, London. Retrieved from http:/www.independent.co.uk/news/ world/europe-turns-a-blind-eye-to-albanian-poll-1349946.html

Hartlyn, J., \& McCoy, J. (2006). Observer paradox: How to assess electoral manipulation. In A. Schedler (Ed.), Electoral authoritarianism: The dynamic of unfree competition (pp. 41-56). Boulder, CO: Lynne Rienner Publishers.

Hartlyn, J., McCoy, J., \& Mustillo, T. (2008). Electoral governance matters: Explaining the quality of elections in contemporary Latin America. Comparative Political Studies, 41, 73-98.

Hyde, S. (2011). The Pseudo-Democrat's dilemma: Why election monitoring became an international norm. Ithaca, NY: Cornell University Press.

Hyde, S., \& Marinov, N. (2012). Which elections can be lost? Political Analysis, 20, 191-210.

Hyde, S., \& O’Mahony, A. (2010). International scrutiny and pre-electoral fiscal manipulation in developing countries. Journal of Politics, 72, 690-704.

International Republican Institute. (1996). IRI observation report on the Albanian parliamentary elections of May, 26, 1996. Washington, DC: Author.

Jowitt, K. (1992). New world disorder: The Leninist extinction. Berkeley: University of California Press.

Keesing's Record of World Events. (Various issues). Available from http://www. keesings.com

Kelley, J. (2009). D-Minus elections: The politics and norms of international election observation. International Organizations, 63, 765-787.

Kelley, J. (2012). Monitoring democracy: When international election observation works, and why it often fails. Princeton, NJ: Princeton University Press.

Kuran, T. (1995). Private truth, public lies: The social consequences of preference falsification. Cambridge, UK: Harvard University Press.

Lijphart, A. (1984). Democracies: Patterns of majoritarian and consensus government in twenty-one countries. New Haven, CT: Yale University Press.

Lijphart, A. (1994). Electoral systems and party systems. Oxford, UK: Oxford University Press.

Linzer, D., \& Staton, J. (2012). A measurement model for synthesizing multiple comparative indicators: The case of judiciary independence. Unpublished manuscript. 
Lust-Okar, E., \& Jamal, A. (2002). Rulers and rules: Reassessing the influence of regime type on electoral law formation. Comparative Political Studies, 35, 337366.

Magaloni, B. A. (2010). The game of electoral fraud and the ousting of authoritarian rule. American Journal of Political Science, 54, 751-765.

Mainwaring, S. (1993). Presidentialism, multipartism, and democracy-The difficult combination. Comparative Political Studies, 26, 198-228.

Maltz, G. (2007). The case for presidential term limits. Journal of Democracy, 18(1), 128-142.

Marshall, M., \& Jaggers, K. (2006). Political regime characteristics and transitions, 1800-2004, Dataset users' manual, Polity IV Project. College Park: University of Maryland.

Melton, J., \& Ginsburg, T. (2012). Does De Jure judicial independence really matter? A reevaluation of explanations for judicial independence. (Chicago Institute for Law and Economics Working Paper No. 612). Retrieved from http://www.law. uchicago.edu/files/file/612-tg-judicial-independence.pdf

Moehler, D., \& Lindberg, S. (2009). Narrowing the legitimacy gap: The role of turnovers in Africa's emerging democracies. Journal of Politics, 71, 1448-1466.

Norris, P. (2004). Electoral engineering: Voting rules and political behavior. Cambridge, UK: Cambridge University Press.

Organization for Security and Co-Operation in Europe. (2004). Georgia parliamentary elections 2 November 2003. Warsaw, Poland: Office for Democratic Institutions and Human Rights.

Orozco-Henriquez, J. (Ed.). (2010). Electoral justice: The international IDEA handbook. Stockholm, Sweden: International IDEA.

Pastor, R. (1999). The role of electoral administration in democratic transitions: Implications for policy and research. Democratization, 6(4), 1-27.

Paxton, P., \& Hughes, M. M. (2007). Women, politics, and power: A global perspective. Thousand Oaks, CA: Pine Forge Press.

Przeworski, A. (1991). Democracy and the market: Political and economic reforms in Eastern Europe and Latin America. Cambridge, UK: Cambridge University Press.

Przeworski, A. (2003). Why do political parties obey results of elections? In M. Maravall \& A. Przeworski (Eds.), Democracy and the rule of law (pp. 114-146). Cambridge, UK: Cambridge University Press.

Reuter, O. J., \& Robertson, G. (2013, May). Cooptation and legislatures in contemporary authoritarian regimes. Paper presented at the Comparative Protest Politics Workshop, Nuffield College, University of Oxford, Oxford, UK.

Roberts, A. (2010). The quality of democracy in Eastern Europe: Public preferences and policy reforms. New York, NY: Cambridge University Press.

Roberts, A., Seawright, J., \& Cyr, J. (2012). Do electoral laws affect women's representation? Comparative Political Studies, 1-27.

Robertson, G. (2007). The politics of protest in hybrid regimes: Managing dissent in post-communist Russia. New York, NY: Cambridge University Press. 
Schedler, A. (2002a). The menu of manipulation. Journal of Democracy, 13(2), 36-50. Schedler, A. (2002b). The nested game of democratization by elections. International Political Science Review, 23, 103-122.

Simpser, A. (2008). Cheating big: On the logic of electoral corruption in developing countries. Unpublished manuscript.

Simpser, A., \& Donno-Panayides, D. (2012). Can international election monitoring harm governance? Journal of Politics, 74, 501-513.

Way, L. (2008). The real causes of the color revolutions. Journal of Democracy, 19(3), 55-69.

World Development Indicators, (2011). Available from http://data.worldbank.org/

\section{Author Biography}

Svitlana Chernykh is a postdoctoral research fellow at the School of Interdisciplinary Area Studies, University of Oxford, UK. She holds a $\mathrm{PhD}$ in political science from the University of Illinois at Urbana-Champaign. Her research interests include comparative political institutions, electoral compliance, and executive-legislative relations. 